\title{
Meta
}

Journal des traducteurs

Translators' Journal

\section{Miao, J. (2006): On the Development of Translation Competence Through Translation Instruction, Tianjin, Tianjin People's Publishing House, $x+193$ p.}

\section{Jianzhong Xu}

Volume 53, numéro 3, septembre 2008

URI : https://id.erudit.org/iderudit/019254ar

DOI : https://doi.org/10.7202/019254ar

Aller au sommaire du numéro

Éditeur(s)

Les Presses de l'Université de Montréal

ISSN

0026-0452 (imprimé)

1492-1421 (numérique)

Découvrir la revue

Citer ce compte rendu

$\mathrm{Xu}$, J. (2008). Compte rendu de [Miao, J. (2006): On the Development of Translation Competence Through Translation Instruction, Tianjin, Tianjin People's Publishing House, $\mathrm{x}+193$ p.] Meta, 53(3), 714-716.

https://doi.org/10.7202/019254ar d'utilisation que vous pouvez consulter en ligne.

https://apropos.erudit.org/fr/usagers/politique-dutilisation/ 
(les investisseurs institutionnels), ses joyaux de la couronne et ses bijoux de famille, ou son Dentiste belge et sa Veuve de Carpentras!), le tout dans une terminologie, par ailleurs, largement imagée (voyez l'interprétation des graphes en papillon, condor et mouette ou encore en arbre de Noël).

L'ouvrage a été salué avec enthousiasme par la critique: pour Le Monde (20/06/06), «après la bible de la Finance d'entreprise [...], cet ouvrage pourrait devenir son équivalent pour les marchés financiers», tandis que Bruno Colmant (L'Écho, 20/03/06) y voit «une source de référence pour les praticiens» et lui reconnaît «un intérêt indéniable pour ceux qui recherchent une analyse systématique du langage de la finance» (Fucam Liaisons, n ${ }^{\circ} 44$, février 2007, p. 14). Nous joignons sans réserves notre modeste part à ces éloges mérités.

Bernard Thiry

Université de Liège, Bruxelles, Belgique

\section{Miao, J. (2006): On the Development of Translation Competence Through Translation Instruction, Tianjin, Tianjin People's Publishing House, $\mathrm{x}+193 \mathrm{p}$.}

More and more translators/interpreters are needed in various fields in our global village, which has led to an emphasis on translation pedagogy to produce eligible, qualified translators/interpreters to meet the needs of an era of globalization and cross-cultural communication. In retrospect, as we examine the teaching of translation in past decades, an emerging problem is conspicuous - the lack of a consistent, systematic and scientific methodology/pedagogy in translation teaching. Translation teaching is featured by anecdotal reflections and fragmentary experience. Therefore, scholars of Translation Studies have come to realize that we need to identify theoretical hypothesis based on actual teaching practice and to construct general principles, rules, and methods that govern or underlie such practice. On the Development of Translation Competence Through Translation Instruction tries to meet this need, and intends to devise a pedagogical model of translation instruction based on consistent, systematic, and appropriate concepts, principles, and the methods that will lay a foundation for translation instruction, and is intended as a contribution to the profession that is in need of such enhancement.

The book comprises five chapters: Introduction, Research on Translation Competence, Empirical Study on Translation Competence, A Model of Translation Instruction, and Conclusion. Its introduction presents an outline that highlights the major points and emphasis of the intended research. The second chapter "Research on Translation Competence" establishes the basis of the contents leading to a logical development of the research. As translation is both a purposeful human activity and a complex mental activity, the translator's performance in fulfilling the tasks requires a unique competence involving a comprehensive application of various knowledge and expertise. It has been a comprehensive competence that has not been adequately described and clearly defined and the development of this unique competence has not been systematically investigated. Translation competence is comprised of interrelated sub-competences and components involved in the translation process. In defining translation competence, the present author intends to analyze translation competence mainly from the cognitive, linguistic and communicative perspectives with the belief that it encompasses three categories contributed by different components. The classification of the three categories manifests a more systematic, comprehensive, hierarchical, and interrelated view on translation competence as a whole. It reflects both a macroscopic examination of the holistic translation competence and a microscopic analysis of the discrete components. In addition, the present author postulates that translation competence is a professional mental competence to deal with complex 
tasks, and such mental expertise distinguishes translation competence from other professional, mental, or behavioral competences. Providing the setting for the analysis of the translation competence, however, the author thinks it is necessary to do an analysis on the translator's role as reader and rewriter, mediator and communicator. Chapter three "Empirical Study on Translation Competence and Translation Process," based on the data analysis of the study of the two groups, Occidental group and Oriental group, reaches the following conclusions: a) When the source text is in the foreign language, the translator produces more misunderstandings, as it is difficult to comprehend. On the other hand when the source text is in the first language, the translator produces much less misunderstandings and feels at ease; b) When the target text is in the foreign language, the translator produces more grammar mistakes including wrong collocation, inappropriate/unnatural/ unidiomatic expressions, whereas when the target text is in the first language, the translator produces few grammar mistakes with good language proficiency. The fourth chapter, based on the findings of the research on translation competence and the empirical study on translation competence, offers a model of translation instruction which includes course design (linguistic/literary, cultural/communicative, theoretical components, translation workshop, translation as critical appreciation, professional/ knowledgeable, seminar/lecture/social practice), curriculum design (organized by the professional craft/skills/techniques, assorted into text types and functions, exemplified with theoretical components, selected for culture learning, and arranged in topics/ issues for seminars, lectures, and activities), quality assessment (placed in a theoretical framework, benefiting from the functionalist propositions and text linguistics analysis), process-orientation in translation teaching - methods and results (teaching process, and translation strategies and decisionmaking process), and computer aid in translation instruction. The last chapter is the conclusion of the book.

The analysis on translation competence is inspiring. It offers an original perspective, dividing the sub-competences with their individual components in an impressive and convincing pattern. It has demonstrated how the sub-competences interrelate effectively to the fulfillment of the complex, multifaceted translation task. In the actual translation process, the translator utilizes, benefits, and develops the competence resources to solve problems, makes decisions, and creates wonders. Based on such delineations, the present author suggests that different aspects be incorporated for developing translation competence. The course design therefore centers on the development of translation competence. The curriculum design is the outcome of the present researcher's teaching experience that has been effective in translation teaching. It presents a demonstration of how theory is incorporated in translation instruction and in fact more often than not, students asked for a good theoretical support for any translation phenomenon.

I am deeply impressed by the empirical case study of think-aloud included in the research which has been a challenging and rewarding process of the research. The research design is original with respect to the theme of the content and the object of study. Taking the rare advantage and opportunity of finding competent Occidental participants at Indiana University (U.S.) and carrying out the other half of the study with correspondent Oriental participants in China, the research is originally and unusually featured with the comparison between the Occidental group and the Oriental group, which highlights the value of this unique study.

The participants in the experiment are ideal for this comparative study. The crucial advantages are that they are all Occidental bilinguals of English and Chinese and of native or near-native English speakers, and they are all academic intellectuals, three of them are $\mathrm{Ph} . \mathrm{D}$. candidates and possess translation experience. Their Chinese is adequate for the contents of the study which are on a higher level. In every respect, they correspond to their Oriental partners in the future study, which is essential for this comparative study. 
In addition, the empirical study of think-aloud translation process and translation competence has met the international research standards concerning content and instruments. The contents reflect most of the development of the empirical model in translation studies. Process study has developed into competence study and the combination of the two, and the results serve for research in translation instruction. The experimental instruments have reached research conditions of the world. Computer systems and language facilities functioned simultaneously to the best observation of the translator performance. The recently developed software for this type of study titled Translog has been applied in the experiment. Translog enables the computer to record all of the keyboard strokes as the participants are translating on the computer. It exhibits the objective translation process of the participants with everything written down - thoughts, corrections, choices, hesitations, difficulties, advantages, and time spent.

Process-orientation is of great importance in translation instruction, which is the central pedagogical emphasis proposed in the research. It allows freedom and flexibility, and encourages thinking and reasoning. Reflections are directed to the translation process by eliciting questions. Students are enlightened as to an understanding of how the translation is coming into being through a concrete process, and they are able to relate the process with their conscious explanation on what they did and will do in translation.

The discussion on computer aid in translation instruction opens a new window to perceive the prospect of translation teaching, which is enriched with effects and efficiency. The computer-aided techniques creating special efforts not only enrich the instruction with audio-visual features but also accumulate diversified translation corpus at the disposal of the instructor.

To sum up, the book has achieved its ultimate aim - to devise a pedagogical model that will serve for establishing criteria for translation teaching, for it has encompassed essential aspects in translation instruction - competence components, skills and strategies, quality assessment, and pedagogy.

JIANZHONG XU 